\title{
Prediction Accuracy Improvement of Indonesian Dairy Cattle Fiber Feed Compositions Using Near-Infrared Reflectance Spectroscopy Local Database
}

\author{
Despal $^{a, *}$, L. A. Sari ${ }^{b}$, R. Chandra ${ }^{b}$, R. Zahera ${ }^{a}$, I. G. Permana ${ }^{a}$, \& L. Abdullah ${ }^{a}$ \\ ${ }^{a}$ Department of Nutrition and Feed Technology, Faculty of Animal Science, IPB University \\ (Bogor Agricultural University) \\ bStudy Program Nutrition and Feed Technology, Department of Nutrition and Feed Technology, Faculty of Animal \\ Science, IPB University (Bogor Agricultural University) \\ Jalan Agatis, Kampus IPB Darmaga Bogor 16680, Indonesia \\ ${ }^{*}$ Corresponding author: despaltk@gmail.com \\ (Received 12-06-2020; Revised 26-07-2020; Accepted 13-08-2020)
}

\begin{abstract}
The accuracy of near infrared reflectance spectroscopy (NIRS) depends on the database generated from the conventional wet chemistry (CWC). Currently, the local database of fiber-source feeds for tropical dairy cattle are still limited. The study aimed to compare CWC and NIRS initial database (NIRSID) results, to predict CWC from NIRSID, and to improve the accuracy of NIRS prediction using local database (NIRSLD). Five feeds as sources of fiber (Napier grass, natural grass, corn leaves, corn husk, and rice straw) from 4 areas of dairy cattle farming were used (4 farms from each area). For external calibration, 20 independent Napier grass samples were tested. Samples were analyzed using NIRS and CWC to measure dry matter (DM), ash, crude protein (CP), ether extract (EE), crude fiber (CF), neutral detergent fiber (NDF), acid detergent fiber (ADF), acid detergent lignin (ADL), and silica (Si) to calculate hemicellulose, cellulose, and lignin contents. The results obtained by NIRSID were compared to those obtained by CWC using T-test. Predictions of CWC from the results obtained by NIRSID were attempted using regressions. The NIRSLD was developed by inputting the CWC value to NIRS spectrums. Internal calibration and validation as well as external calibration, were run. The results showed that NIRSID has low capacity in determining CWC $(\mathrm{R} 2<0.683)$. Calibration using local database (NIRSLD) improved CWC prediction accuracy (residual predictive deviation (RPD) $>2$ except for DM, EE, CF, ADL, and lignin). External validation showed that CWC and NIRSLD were similar in all parameters $(\mathrm{p}<0.05)$. The ratios of the standard error of prediction (SEP) to the standard error of laboratory (SEL) were $>2$ for $\mathrm{CP}, \mathrm{CF}$, and ADF. It is concluded that the local database of NIRS of fibersource feeds is necessary to improve the prediction accuracy of local dairy fiber-source feeds values using NIRS.
\end{abstract}

Keywords: dairy cattle; databases; fiber feed source; NIRS; prediction

\section{INTRODUCTION}

Feedstuff compositions are important in formulating ration to fulfill animal requirements (Hall, 2014). The data needed include proximate composition (DM, CP, $\mathrm{EE}, \mathrm{CF}$, and nitrogen free extract (NFE)), cell wall fraction (NDF, ADF, ADL, hemi-cellulose, cellulose, lignin, and silica), rumen fermentability, and digestibility. The chemical and utility values of feedstuffs can be analyzed using CWC methods or called chemo-metrics such as proximate analysis (AOAC, 2015) to analyze chemical compositions, van Soest method (Van Soest et al., 1991) to analyze cell wall structures, as well as two stage method (Tilley \& Terry, 1963) to analyze rumen fermentability and digestibility.

One alternative method to the analysis is the NIRS method. NIRS method has advantages for its fast, low cost, non-destructive, and no chemical requirements for solvents or reagents (Parrini et al., 2018). The NIRS method has been used in analyzing several chemical parameters (Pierna et al., 2011) for several purposes such as moisture content during the drying process (Phetpan et al., 2019), sugar content in potatoes (Rady \& Guyer, 2015), total phenols, condensed tannins, and 3-deoxyanthocyanidins in sorghum grain (Dykes et al., 2014), and the digestibility of feedstuffs (Samadi et al., 2018).

The accuracy of the NIRS method depends on the database used in the calibration process by the NIRS instrument (Hall, 2014). The calibration process involved data acquired from the CWC methods to develop a database (Soldado et al., 2013). Initial NIRS database (NIRSID) that come together with the instrument was not only expensive but also less accurate to be used for local feedstuffs. The database provided by the instrument was developed mostly based on temperate or subtropical feedstuffs that might differ from tropical feedstuffs (Cooke et al., 2020) due to different species used, age at harvesting, and range of nutrient concentrations in the similar feedstuffs. Some unconventional fiber-source feeds used in a dairy farm in a tropical area such as rice straw, corn husk, and corn stover (Lestari et al., 2015) might have different spectrums, out of the 
range of the initial database, and difficult to analyze using NIRSID accurately. Some important nutrients information for the formulation of dairy cattle ration, such as cellulose and hemicellulose might not be available because of the initial general purposes of database designs. Therefore, NIRS database calibration for local fiber-source feeds with relevant parameters of dairy cattle needs to be developed.

Smallholder dairy farms in Indonesia used locally available fiber-source feeds such as Napier grass, natural grass, rice straw, corn stover, and cornhusk as the main ration components. The fiber-source feeds used in daily ration changes rapidly according to its availability which affects milk production and persistency because their interchanges are not reformulated correctly. Daily milk production measured in a similar farm drop rapidly from $22-20 \mathrm{~L}$ at $2^{\text {nd }}-4^{\text {th }}$ month in milk (Hasanah et al., 2017) to $18-16 \mathrm{~L}$ at the $3^{\text {rd }}-5^{\text {th }}$ month in milk (Zahera et al., 2015), and $12-10 \mathrm{~L}$ at the $6^{\text {th }}-7^{\text {th }}$ month in milk (Nugroho et al., 2015). With the fast-detection properties of NIRS, the rapid changing in fiber-source feeds can be measured and reformulated.

This research was aimed at comparing the qualities of dairy fiber-source feeds resulted from CWC analysis and NIRS prediction using an initial database (NIRSID), making a prediction of CWC from NIRSID results to adjust the prediction accuracy, and to develop NIRS local dairy fiber-source feeds database (NIRSLD) for higher accuracy and complete measurements of nutritive values of tropical dairy fiber-source feeds

\section{MATERIALS AND METHODS}

\section{Sample Preparations}

Five main fiber-source feeds used in dairy cattle farms in Indonesia were used. They were Napier grass, natural grass, rice straw, corn stover, and cornhusk. The fiber-source feeds were collected from four dairy cattle main areas in West Java Province of Indonesia (Pangalengan District of Bandung Regency, Lembang District of West Bandung Regency, Parung Kuda District of Sukabumi Regency, and Cibungbulang District of Bogor Regency). For each area, four dairy farms were sampled for fiber-source feeds used in the farm. For external validation, 20 complete independent sets of Napier grass samples from different locations in Bogor City and Regency were used. In total, 100 fiber-source feeds samples were used in this research.

\section{Wet Chemical Analysis}

Two kilograms of fiber-source feeds used in each farm were sampled, dried in Eyela NDO 400 (made in Japan) oven at $60^{\circ} \mathrm{C}$ for 48 hours, ground using laboratory blender at medium speed, and then filtered to pass a $1 \mathrm{~mm}$ screen. The powder samples were stored in a separate polyethylene plastic bag for each sample to be used later. Wet chemical analyses were conducted (AOAC, 2015) to measure proximate compositions (DM, Ash, $\mathrm{CP}, \mathrm{EE}$, and $\mathrm{CF}$ ). The proximate analysis used the Eyela Oven to determine dry matter (DM) content. Soxhlet and Kjeldahl systems from Gerhart Instruments (made in Germany) were used to determine EE and CP, respectively.

Concentrations of NDF were measured after digestion in neutral detergent solution (NDS) followed by heat-stable $\alpha$-amylase and sodium sulfite using the batch procedures (Method 15) recommended for an Ankom200 Fiber Analyzer (Ankom Technology Corp., Macedon, NY). Subsequently, NDF residues were continued with digestion with acid detergent solution (ADS) to measure ADF using Method 14 recommended for the Ankom200. The ADF residues were further dissolved in sulfuric acid for $3 \mathrm{~h}$ to determine ADL (Method 8) and then corrected for residual ash by combustion in a muffle furnace at $500^{\circ} \mathrm{C}$ for $6 \mathrm{~h}$. Procedures for calculations of NDF, ADF, ADL, and silica followed the formulas of Van Soest et al. (1991). Crude fiber determination was conducted by following AOCS Approved Procedure Ba 6a-05 (AOCS, 2005) recommended for crude fiber analysis in feeds by filter bag technique (Ankom200), including digestion in acid and alkaline solutions.

\section{Measurement Feed Quality Using NIRS}

The modular FT-NIR Spectrometer Solids Cell (BUCHI; NIRFlex N-500 made in Switzerland) was used to analyze proximate and cell-wall compositions. Before being used, the NIRS was warmed up for approximately 15 minutes. Once the instrument was warmed up, the NIRS was automatically run the system suitability test (SST) to verify the NIRS performance periodically. After completing SST, external and internal references were run using the application of NIRSware operator. Before running the reference tests, an external reference (provided by BUCHI) had been inserted into the external-reference holder. NIRS was ready to be used after completing the reference measurement.

Before sample measurements, a database used should be selected from internal applications of NIRSware operator (NIRSID). Sample measurement was conducted by putting the sample (50 g dried fiber-feed mash) in a petri dish add-on with $100 \mathrm{~mm}$ diameter of glass dish for solid sample (powder dried fiber-source feed). The sample should be distributed evenly and cover all the dishes. The dish should be put into the petri dish holder to measure the spectrum. The near infra-red light was sent into the sample and measured its absorbance at various wavelengths (800-2500 $\mathrm{nm}$ or 12500-4000 $\mathrm{cm}^{-1}$ ) allowing for sample identification by penetrating the sample up to several millimeters deep. The scanning was done three times for each sample. The results will be automatically calculated as an average. The software marked the outrange sample automatically and, therefore, should be excluded from the results.

Database development was done using a similar procedure as sample measurement. However, in this step, no database was selected. The collected spectra were input with chemo-metric results with the help of NIRSware Management Console. Using NIRCal V5.6, calibration and validation of the database were 
conducted. The collected spectra were automatically divided into $2 / 3$ for calibration and $1 / 3$ for validation using block-wise methods. Calibration models used partial least square regression while validation models used a validation set. The calibration and validation processes produced a comparison between chemo-metric and NIRS prediction values. The database resulted from the calibration and validation processes can be used as standard references for subsequent measurement after external validation. The best models generated were selected based on the smallest standard error of calibration (SEC) and standard error of prediction (SEP) with the highest calibration coefficients $\left(R^{2}\right)$ and residual predictive deviation (RPD). RPD is a ratio between the standard deviation (SD) to SEP. External validation was conducted by measuring samples using a new database (NIRSLD) and the results were validated with chemometrics results. The comparison values of the standard error of prediction to the standard error of laboratory (SEP/SEL) were calculated.

\section{Research Design and Data Analysis}

This study used field explorative and laboratory research. Data analysis was conducted using T-test to compare CWC and NIRSID or NIRSLD data. Prediction of CWC values from NIRSID were done using regression after correlation analysis to include the correlated parameters into the estimated model. Calibration and validation of databases were conducted using partial least squares from NIRCal V5.6.

\section{RESULTS}

\section{Comparison between NIRSID and CWC}

Two general types of feed assay, chemical (sometimes called "wet chemistry") and near infrared (NIR) reflectance were compared in this study. Table 1 showed that the values of fiber-source feeds obtained from
NIRSID were similar to CWC values for DM, Ash, and $\mathrm{CF}$, ADL, silica, hemicellulose, and cellulose parameters. However, the values were different for $\mathrm{CP}, \mathrm{EE}, \mathrm{NDF}$, and ADF parameters.

\section{Prediction CWC Value from NIRSID}

An effort to improve the accuracy of measurement by adjustment of NIRSID values was made by using a prediction model regression from the correlated parameters. The results of correlation tests between CWC and NIRSID data are shown in Table 1. The correlation coefficients between related parameters were high $(\mathrm{R}>0.7)$ for Ash, NDF, and ADF, but were low $(R<0.7)$ for $D M$, $\mathrm{CP}, \mathrm{EE}$, and CF. Adjustment of CWC from NIRSID data were made for the high correlation coefficient parameters, as were shown in Table 2. The highest regression value was found in ash $\left(R^{2}=0.764\right)$, which resulted in more than $23 \%$ unpredicted factors.

\section{Development of Local NIRS Dairy Fiber-Source Feeds Database}

Spectra produced from the inputting local fibersource feeds database (NIRSLD) are shown in Figure 1. The spectra showed a range of 4000 to $10000 \mathrm{~cm}^{-1}$. This spectrum contained physical and chemical information about molecules. However, the information cannot be extracted directly because NIR spectra consists of a number of overlap bands (multicollinearity), the poor signal to noise (SN) ratios, and baseline fluctuations (Ozaki et al., 2007). The various peaks shown in this figure came from overlapping absorptions, which related mainly to overtones and combinations of vibrational modes involving some useful chemical bonds $(\mathrm{C}-\mathrm{H}$, $\mathrm{O}-\mathrm{H}, \mathrm{N}-\mathrm{H}$, and $\mathrm{S}-\mathrm{H})$. These absorption bands are indications of major unique constituents in the samples.

Calibration and validation of the local dairy fibersource feeds database is shown in Table 3 for proximate compositions and cell wall structures. The table showed

Table 1. Comparison of proximate values of tropical fiber-source feeds using CWC and NIRSID

\begin{tabular}{|c|c|c|c|c|}
\hline Parameters & CWC & NIRSID & T-Test & $\mathrm{R}$ \\
\hline \multicolumn{5}{|l|}{ Proximate compositions } \\
\hline Dry matter (\%) & $90.23 \pm 1.54$ & $90.48 \pm 1.59$ & 0.242 & 0.286 \\
\hline Ash (\% DM) & $11.56 \pm 5.63$ & $11.80 \pm 5.28$ & 0.586 & 0.760 \\
\hline Crude protein (\% DM) & $8.36 \pm 2.23^{a}$ & $9.30 \pm 3.20^{\mathrm{b}}$ & 0.000 & 0.698 \\
\hline Ether extract (\% DM) & $2.34 \pm 0.56^{\mathrm{b}}$ & $1.36 \pm 1.14^{\mathrm{a}}$ & 0.000 & 0.256 \\
\hline Crude fiber (\% DM) & $28.65 \pm 3.09$ & $29.20 \pm 3.48$ & 0.133 & 0.515 \\
\hline \multicolumn{5}{|l|}{ Cell wall structures } \\
\hline NDF (\% DM) & $61.68 \pm 6.57^{b}$ & $55.67 \pm 7.91^{\mathrm{a}}$ & 0.000 & 0.817 \\
\hline $\mathrm{ADF}(\% \mathrm{DM})$ & $33.54 \pm 3.82^{\mathrm{a}}$ & $36.75 \pm 3.76^{b}$ & 0.000 & 0.744 \\
\hline ADL (\% DM) & $4.72 \pm 2.23$ & $\mathrm{~N} / \mathrm{A}$ & N/A & N/A \\
\hline Hemicellulose (\% DM) & $28.15 \pm 5.27$ & $\mathrm{~N} / \mathrm{A}$ & N/A & N/A \\
\hline Cellulose (\% DM) & $28.82 \pm 3.18$ & $\mathrm{~N} / \mathrm{A}$ & N/A & $\mathrm{N} / \mathrm{A}$ \\
\hline Lignin (\% DM) & $3.31 \pm 1.12$ & N/A & N/A & N/A \\
\hline Silica (\% DM) & $1.41 \pm 1.84$ & N/A & N/A & N/A \\
\hline
\end{tabular}

Note: $\mathrm{NDF}=$ neutral detergent fiber, $\mathrm{ADF}=$ acid detergent fiber, $\mathrm{ADL}=$ acid detergent lignin, $\mathrm{CWC}=$ conventional wet chemistry, $\mathrm{NIRSID}=$ near infrared reflectance spectroscopy initial database, $\mathrm{R}=$ coefficient correlation, means in the same row with different superscripts differ significantly ( $\mathrm{p}<0.05$ ) 
Table 2. Prediction of wet chemical proximate and cell wall compositions from NIRSID

\begin{tabular}{cccccccc}
\hline Y & Constant & X & X2 & X3 & X4 & X5 & R2 \\
\hline DM & 63.99 & 0.2936 & & & & 0.0816 \\
Ash & 30.457 & -13.868 & 2.6583 & -0.2145 & 0.0079 & -0.0001 & $0.7637^{*}$ \\
CP & 65.825 & -26.613 & 3.4264 & -0.0207 & -0.0199 & 0.0009 & $0.5238^{*}$ \\
EE & 2.6639 & -0.9144 & -0.0819 & 0.4404 & -0.1376 & 0.0124 & $0.5135^{*}$ \\
CF & -4690.3 & 913.54 & -69.91 & 2.6433 & -0.0494 & 0.0004 & $0.3298^{*}$ \\
NDF & 82.353 & -3.8474 & 0.086 & -0.0005 & & & $0.6727^{*}$ \\
ADF & -0.0651 & -0.2124 & 0.0916 & -0.0015 & & & $0.6832^{*}$ \\
\hline
\end{tabular}

Note: $\mathrm{NIRSID}=$ near infrared reflectance spectroscopy initial database, $\mathrm{DM}=$ dry matter, $\mathrm{CP}=$ crude protein, $\mathrm{EE}=$ ether extract, $\mathrm{CF}=\mathrm{crude}$ fiber, $\mathrm{NDF}=$ neutral detergent fiber, $\mathrm{ADF}=$ acid detergent fiber, $\mathrm{Y}=$ conventional wet chemical value, $\mathrm{X}=$ near infrared reflectance spectroscopy initial database value, $R 2=$ coefficient determination, ${ }^{*}=\mathrm{p}<0.05$.

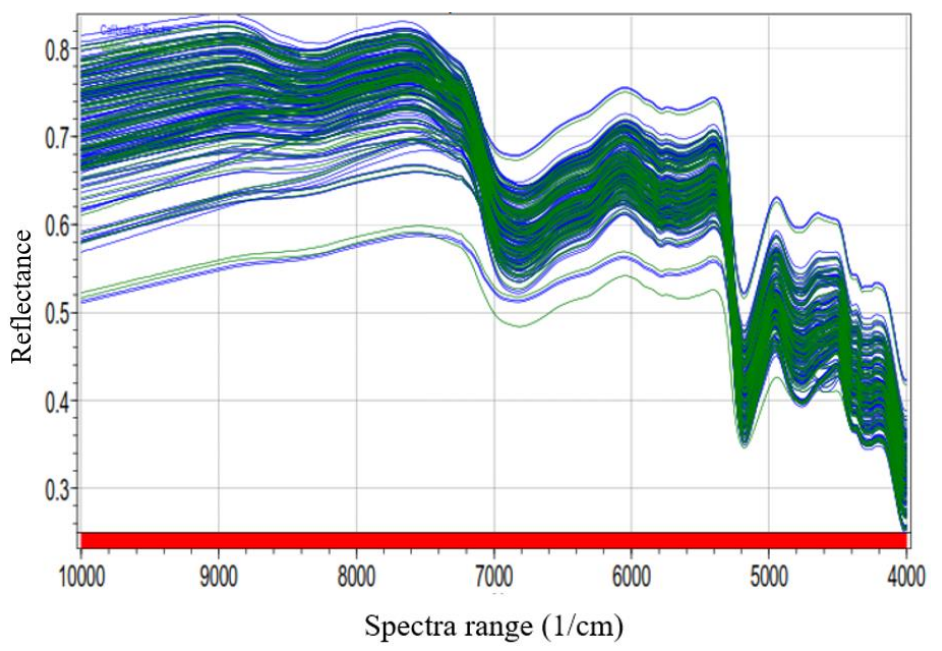

Figure 1. Spectrum collected from local fiber-source feeds

Table 3. Calibration and validation statistics in NIRSLD models for estimation of nutrient content (proximate) of tropical fiber-source feeds

\begin{tabular}{|c|c|c|c|c|c|c|c|c|c|c|c|c|c|c|}
\hline \multirow{2}{*}{ Parameters } & \multicolumn{7}{|c|}{ Calibration } & \multicolumn{7}{|c|}{ Validation } \\
\hline & $\mathrm{n}$ & Mean & Range & SD & SEC & $\mathrm{R} 2 \mathrm{C}$ & RPD & $\mathrm{n}$ & Mean & Range & SD & SEP & R2V & RPD \\
\hline $\mathrm{DM}(\%)$ & 160 & 90.23 & $85.17-93.18$ & 1.346 & 0.744 & $0.766^{*}$ & 1.809 & 80 & 90.21 & $85.17-93.18$ & 1.305 & 0.749 & $0.765^{*}$ & 1.743 \\
\hline Ash (\% DM) & 160 & 11.55 & $2.43-24.49$ & 5.412 & 1.501 & $0.929^{*}$ & 3.605 & 80 & 11.46 & $2.43-24.49$ & 5.318 & 1.521 & $0.928^{*}$ & 3.497 \\
\hline $\mathrm{CP}(\% \mathrm{DM})$ & 160 & 8.36 & $4.25-12.87$ & 2.059 & 0.828 & $0.861^{*}$ & 2.487 & 80 & 8.29 & $4.25-12.87$ & 2.127 & 0.853 & $0.883^{*}$ & 2.494 \\
\hline $\mathrm{EE}(\% \mathrm{DM})$ & 160 & 2.36 & $1.26-4.13$ & 0.418 & 0.413 & $0.506^{*}$ & 1.012 & 80 & 2.37 & $1.26-4.13$ & 0.418 & 0.419 & $0.496^{*}$ & 0.998 \\
\hline $\mathrm{CF}(\% \mathrm{DM})$ & 160 & 28.66 & $17.3-35.8$ & 2.594 & 1.660 & $0.710^{*}$ & 1.563 & 80 & 28.65 & $17.3-35.8$ & 2.540 & 1.720 & $0.690^{*}$ & 1.477 \\
\hline $\mathrm{NDF}(\% \mathrm{DM})$ & 160 & 47.62 & $33.8-77.41$ & 6.163 & 2.153 & $0.891^{*}$ & 2.862 & 80 & 48.94 & 33.8-77.41 & 6.142 & 2.230 & $0.884^{*}$ & 2.755 \\
\hline $\mathrm{ADF}(\% \mathrm{DM})$ & 160 & 33.53 & $18.63-41.11$ & 3.418 & 1.688 & $0.804^{*}$ & 2.025 & 80 & 33.56 & $18.63-41.11$ & 3.373 & 1.686 & $0.806^{*}$ & 2.001 \\
\hline $\mathrm{ADL}(\% \mathrm{DM})$ & 160 & 4.53 & $0-11.14$ & 1.632 & 1.086 & $0.754^{*}$ & 1.504 & 80 & 4.50 & $0-11.14$ & 1.636 & 1.069 & $0.768^{*}$ & 1.530 \\
\hline $\begin{array}{l}\text { Hemicellulose (\% } \\
\text { DM) }\end{array}$ & 160 & 28.00 & $15.17-39.21$ & 4.659 & 1.868 & $0.862^{*}$ & 2.494 & 80 & 28.08 & $15.17-39.21$ & 4.671 & 1.888 & $0.859^{*}$ & 2.474 \\
\hline Cellulose (\% DM) & 160 & 28.82 & $16.54-35.42$ & 2.877 & 1.334 & $0.823^{*}$ & 2.157 & 80 & 28.82 & $16.54-35.42$ & 2.897 & 1.350 & $0.820^{*}$ & 2.145 \\
\hline Lignin (\% DM) & 160 & 3.32 & $0.9-7.18$ & 0.945 & 0.607 & $0.708^{*}$ & 1.557 & 80 & 3.33 & $0.9-7.18$ & 0.933 & 0.634 & $0.683^{*}$ & 1.471 \\
\hline Silica (\% DM) & 160 & 1.41 & $0-11.53$ & 1.663 & 0.774 & $0.822^{*}$ & 2.147 & 80 & 1.36 & $0-11.53$ & 1.603 & 0.784 & $0.820^{*}$ & 2.045 \\
\hline
\end{tabular}

Note: NIRSID $=$ near infrared reflectance spectroscopy initial database, $n=$ total number of observation, $\mathrm{DM}=$ dry matter, $\mathrm{CP}=$ crude protein, $\mathrm{EE}=\mathrm{ether}$ extract, $\mathrm{CF}=$ crude fiber, $\mathrm{NDF}=$ neutral detergent fiber, $\mathrm{ADF}=$ acid detergent fiber, $\mathrm{ADL}=$ acid detergent lignin, $\mathrm{SD}=$ standard deviation, $\mathrm{SEC}=$ standard error of calibration, $\mathrm{R} 2 \mathrm{C}=$ coefficient determination of calibration, $\mathrm{RPD}=$ residual predictive deviation, $\mathrm{SEP}=$ standard error of prediction, $\mathrm{R} 2 \mathrm{~V}=$ coefficient determination of validation, ${ }^{*}=\mathrm{p}<0.05$.

that the local database produced a better statistical value with high $\mathrm{R}^{2} \mathrm{C}(>0.7)$ and low SEC $(<2.153)$. The highest $\mathrm{R}^{2} \mathrm{C}$ was found in ash prediction $\left(\mathrm{R}^{2} \mathrm{C}=0.929\right)$. The $\mathrm{R}^{2} \mathrm{Cs}$ for $\mathrm{CP}, \mathrm{NDF}, \mathrm{ADF}$, hemicellulose, cellulose, and silica were $>0.8$. Calibration made using the local database of fiber-source feeds improved coefficient of determination
$\left(\mathrm{R}^{2} \mathrm{C}\right)$ from 0.524 to 0.828 for $\mathrm{CP}$, from 0.672 to 0.891 for $\mathrm{NDF}$, and from 0.683 to 0.804 for ADF.

External validation of database (NIRSLD) using 20 samples of Napier grass from different locations are presented in Table 4 . The results showed that NIRSLD values were not significantly different from CWC for 
Table 4. External validation statistics of nutrient contents on tropical fiber-source feeds

\begin{tabular}{cccccccc}
\hline Parameters & CWC & NIRSLD & T-Test & R & SEL & SEP & SEP/SEL \\
\hline DM $(\%)$ & $91.00 \pm 2.44$ & $89.95 \pm 0.84$ & 0.065 & $0.517^{*}$ & 1.642 & 2.232 & 1.359 \\
Ash $(\%$ DM) & $13.60 \pm 2.70$ & $13.82 \pm 1.99$ & 0.763 & $0.770^{*}$ & 1.130 & 2.186 & 1.934 \\
CP (\% DM) & $10.08 \pm 2.91$ & $11.34 \pm 0.73$ & 0.067 & $0.597^{*}$ & 1.013 & 2.593 & 2.560 \\
CF (\% DM) & $28.62 \pm 3.76$ & $28.58 \pm 2.06$ & 0.964 & $0.771^{*}$ & 0.827 & 2.780 & 3.361 \\
NDF (\% DM) & $60.41 \pm 3.56$ & $58.79 \pm 4.38$ & 0.208 & $0.681^{*}$ & 2.004 & 3.150 & 1.572 \\
ADF (\% DM) & $34.14 \pm 3.30$ & $34.00 \pm 2.32$ & 0.879 & $0.888^{*}$ & 0.929 & 1.953 & 2.102 \\
\hline
\end{tabular}

Note: $\mathrm{DM}=$ dry matter, $\mathrm{CP}=$ crude protein, $\mathrm{EE}=$ ether extract, $\mathrm{CF}=$ crude fiber, $\mathrm{NDF}=$ neutral detergent fiber, $\mathrm{ADF}=$ acid detergent fiber, $\mathrm{ADL}=$ acid detergent lignin, $\mathrm{CWC}=$ conventional wet chemistry, NIRSLD $=$ near infrared reflectance spectroscopy local database, $\mathrm{R}=$ coefficient correlation, $\mathrm{SEL}=$ standard error of laboratory, $\mathrm{SEP}=$ standard error of prediction, ${ }^{*}=\mathrm{p}<0.05$.

all parameters measured. The coefficient correlation between CWC and NIRSLD was high $(\mathrm{R}>0.5)$, higher than the coefficient correlations between CWC and NIRSID (Table 1) for DM, ash, CF, and ADF. Comparison or ratios of SEP/SEL were $<2$ for DM, Ash, and NDF, while for $\mathrm{CP}, \mathrm{CF}$, and $\mathrm{ADF}$ the ratios were $>2$.

\section{DISCUSSION}

\section{Comparison between NIRSID and CWC}

The significantly different values between NIRSID and CWC were especially found for the complex organic compounds of high molecular weight (Lozano, 2015). The differences were due to the different ranges of database used in NIRS for local fiber-source feeds for dairy cattle in Indonesia. Dried ruminant fiber-source feeds database used in Buchi NIRFlex N-500 Solids Cell (NIRSID) might be developed mostly using temperate forage, which was very different from tropical forages both species and nutrient contents. The different nutrient contents of tropical and subtropical forages were might also due to the different light intensities and daylengths (Cooke et al., 2020), different forage species used and different generative stages of the plants (Sriagtula et al., 2017), and different ages at the harvesting of the plants (Puteri et al., 2015).

The CP, NDF, and ADF values were common measures of protein and fiber contents of feed used in ruminant (van Soest et al., 1991), especially in dairy nutrition (Hammond et al., 2016) which can be used in determination of forage relative value (RFV) system (Olafadehan \& Okunade, 2018). Accurate measurements of these parameters will determine the ration quality and affect feed intake (Riaz et al., 2014), digestibility (Stergiadis et al., 2015), and dairy performance (Krämer-Schmid et al., 2016). High CP in ration will increase milk production (Mutsvangwa et al., 2016), while high NDF and ADF are related to a low digestibility (Stergiadis et al., 2015) and are considered as two important limited factors for the estimation of the nutritive qualities of feed and forage (Wolfrum et al., 2009). Because CP, NDF, and ADF are important for dairy nutrition as indicators of protein and fiber availabilities for the animal and milk synthesis, the accuracies of these parameters' measurements are very important.

\section{Prediction CWC Value from NIRSID}

Models to predict $\mathrm{CP}, \mathrm{EE}, \mathrm{NDF}$, and ADF values had lower $\mathrm{R}^{2}(<0.68)$, which showed that adjustments of CWC values from NIRSID were inaccurate. An effort to improve the accuracies of NIRSID predictions of $\mathrm{CP}, \mathrm{NDF}$, and ADF could not be done by adjusting the NIRSID value through the regression model. The adjustment of NIRSID values to achieve CWC values can be made by using regression if the values have high correlations (Yin, 2020). Low correlations of NIRSID values to $C W C$ values found in this study resulted in the low NIRSID prediction capacity of CWC values. The accuracy of NIRS in predicting CWC was higher by using a single forage species (Yang et al., 2017) or by developing NIRS calibration equations for individual species or groups of similar forage species (Fairbrother \& Brink, 1990). Lower prediction accuracies using NIRS for NDF and ADF were also reported by Hoffman et al. (1999). Therefore, it needs a new pre-calibrated database with local CWC data before it's used in NIRS.

\section{Development of Local NIRS Dairy Fiber-Source Feeds Database}

The near-infrared spectrum was located from 2500 $\mathrm{nm}$ to $800 \mathrm{~nm}$ or from $4000 \mathrm{~cm}^{-1}$ to $12,500 \mathrm{~cm}^{-1}$ (Ozaki et al., 2007). However, the region of 4000 to $9000 \mathrm{~cm}^{-1}$ were the most prominent bands to absorb polymers originating from $\mathrm{OH}, \mathrm{NH}, \mathrm{CH}$, and $\mathrm{SH}$ overtone stretching vibrations and stretching-bending combinations. Yang et al. (2017) found the critical wavelengths to construct optimal NIRS models for Italian ryegrass were located at 4247-6102, 4247-5450, and 5446-6102 $\mathrm{cm}^{-1}$ for CP, NDF, and ADF contents, respectively. The precise and proper spectral analysis of NIR spectra allows us to get useful information from NIR spectra, whereas improper spectral analysis may lead to the wrong information (Ozaki et al., 2007). In this study, adjustment made in the range of $4200-6200 \mathrm{~cm}^{-1}$ did not improve CP, NDF, and ADF statistical parameters significantly. The difficulties in determining what wavelength or region accurately in the near-infrared spectrum carrying the most quantitative information about the contents of natural compounds were also found by Saha et al. (2017). This problem might be caused by the wider range of substrate available in the local dairy fiber-source feeds in comparing to Italian ryegrass found by Yang et al. (2017). Several 
species of natural grass found such as Panicum repens, Cynodon dactylon Pers, Leersia hexandria, Brachiaria mutica, Cyperus rotundus L, and Trichola enarosea (Despal et al., 2017) might contain an abundance of some specific functional groups of various organic compounds (Saha et al., 2017).

The high determination coefficient $\left(\mathrm{R}^{2} \mathrm{C}>0.8\right)$ found in this study indicated a good prediction of calibration models. Moreover, $\mathrm{R}^{2} \mathrm{C}=0.929$ for the ash parameter indicated an excellent prediction of the calibration model (Williams \& Sobering 1993). Even though some mineral absorptions might be absent in the near-infrared region, it was still possible to estimate ash contents accurately. This condition was probably due to complexes of ash with organic compounds (Parrini et al., 2018).

The ratio of prediction to the deviation (RPD) after partial least square regression found was higher than 2 for $\mathrm{CP}(\mathrm{RPD}=2.487)$, NDF $(\mathrm{RPD}=2.862)$, and ADF $(\mathrm{RPD}=2.025)$, hemicellulose, cellulose, and silica. While, the RPD $<2$ were found in DM, EE, CF, ADL, and lignin. Internal validation of the data resulted in almost similar statistics parameters. The RPD is the ratio of the SD to SEP. This value represented the ability of the NIRS model to predict a substance (Williams \& Sobering, 1993). According to Baillères et al. (2002), SEP data alone may be misleading, therefore, the RDP value is needed. An RPD value of more than 2 was categorized as a relevant prediction of NIRS. If the SEP value closed to the $\mathrm{SD}$ value $(\mathrm{RPD}<2)$, the NIRS calibration process was not efficient in predicting chemo-metric value. In this study, NIRS local dairy fiber-source feeds database developed (NIRSLD) was relevant in predicting CWC because RPD value found for $\mathrm{CP}, \mathrm{NDF}$, ADF, hemicellulose, cellulose, and silica were higher than 2 . However, Lobos et al. (2013) gave a higher category (RPD>2.5) as a valid measurement ability of a NIRS model to predict a constituent. In this case, the ADF database produced needs to be improved. The low RPD found in the prediction of $\mathrm{ADL}$ and lignin $(\mathrm{RPD}<2)$ in this study might be caused by the presence of polyphenolic compounds that can alter the lignin absorption bands located in the same spectral zones (Baillères et al., 2002). Williams (2004) suggested five categories of prediction accuracy based on RPD values, i.e., 1) The RPD $<1.5$ indicated an unusable; 2 ) The $1.5<\mathrm{RPD}<2.0$ grouped as the ability of prediction to distinguish between high and low values; 3) The $2.0<\mathrm{RPD}<2.5$ produced an "approximate" quantitative prediction; 4 ) The $2.5<\mathrm{RPD}<3.0$ reflected a "good" quantitative prediction; and 5) The RPD $>3.0$ indicated an "excellent" quantitative prediction.

Improvement of prediction value of Napier grass CWC from NIRSLD is caused by the similarities in database input into the spectrum. The prediction error relative (PRL) was needed for further evaluation of the model accuracy. The PRL was the ratio of the SEP to the SEL values (Yang et al., 2017). In this study, it was found that PRL for CP and ADF were more than 2; therefore, they need to be improved. The SEP should closely match the SEL. If SEP was much more than the SEC, then it could be an indication of too many wavelengths in the models that do not represent the substrate being modeled (Ozaki et al., 2007).

\section{CONCLUSION}

Low prediction accuracy of dairy cattle fiber feed using initial NIRS database can be overcome by development local database. The improvements are mainly in prediction of protein and fiber fractions. More chemometric samples of single species fiber feed are needed to be able to further improve the prediction accuracy.

\section{CONFLICT OF INTEREST}

Luki Abdullah serves as an editor of the Tropical Animal Science Journal, but has no role in the decision to publish this article. The authors certify that there is no conflict of interest with any financial organization regarding the material discussed in the manuscript.

\section{ACKNOWLEDGEMENT}

This research was funded by Indonesian Ministry of Education within the Scheme of National Competitive Basic Research 2020 with contract No 3984/IT3.L1/ PN2020 and support by The Netherlands Initiative for Capacity Development in Higher Education (NICHE) within the framework of Animal Logistic Indonesia Netherland Project (IDN- 223).

\section{REFERENCES}

AOAC. 2015. Official Methods of Analysis of AOAC International. 20th ed. Arlington: Assoc. Off. Anal. Chem.

AOCS. 2005. Official Methods and Recommended Practices of the AOCS. $7^{\text {th }}$ ed. Urbana: The American Oil Chemists' Society.

Baillères, H., F. Davrieux, \& F. Ham-Pichavant. 2002. Near infrared analysis as a tool for rapid screening of some major wood characteristics in a Eucalyptus breeding program. Annals of Forest Sci. 59: 479-90. https://doi.org/10.1051/ forest:2002032

Cooke, R. F., C.L. Daigle, P. Moriel, S.B. Smith, L.O. Tedeschi, \& J.M. Vendramini. 2020. Cattle adapted to tropical and subtropical environments (I): Social, Nutritional, and carcass quality considerations. Anim. Sci. J. 98 (2). https://doi. org/https://doi.org/10.1093/jas/skaa014

Despal, I.G. Permana, T. Toharmat, \& D.E. Amirroennas. 2017. Pemberian Pakan Sapi Perah. 1st ed. IPB Press, Bogor.

Dykes, L., L. Hoffmann, O. Portillo-Rodriguez, W. L. Rooney, \& L. W. Rooney. 2014. Prediction of total phenols, condensed tannins, and 3-deoxyanthocyanidins in sorghum grain using near-infrared (NIR) spectroscopy. J. Cereal Sci. 60: 138-42. https://doi.org/10.1016/j.jcs.2014.02.002

Fairbrother, T. E. \& G. E. Brink. 1990. Determination of cell wall carbohydrates in forages by near infrared reflectance spectroscopy. Anim. Feed Sci. Technol. 28: 293-302. https:// doi.org/10.1016/0377-8401(90)90160-A

Hall, M. B. 2014. Feed analyses and their interpretation. Vet. Clin. North Am. - Food Anim. Practice. 30: 487-505. https:// doi.org/10.1016/j.cvfa.2014.07.001

Hammond, K. J., A. K. Jones, D. J. Humphries, L. A. Crompton, \& C. K. Reynolds. 2016. Effects of diet forage source and neutral detergent fiber content on milk production of dairy cattle and methane emissions determined using greenfeed and respiration chamber techniques. J. Dairy Sci. 99: 790417. https://doi.org/10.3168/jds.2015-10759

Hasanah, U., I. G. Permana, \& Despal. 2017. Introduction of complete ration silage to substitute the conventional ration 
at traditional dairy farms in Lembang. Pakistan J. Nutr. 16: 577-87. https://doi.org/10.3923/pjn.2017.577.587

Hoffman, P. C., N. M. Brehm, L. M. Bauman, J. B. Peters, \& D. J. Undersander. 1999. Prediction of laboratory and in situ protein fractions in legume and grass silages using nearinfrared reflectance spectroscopy. J. Dairy Sci. 82: 764-70. https://doi.org/10.3168/jds.S0022-0302(99)75294-X

Krämer-Schmid, M., P. Lund, \& M. R. Weisbjerg. 2016. Importance of NDF digestibility of whole crop maize silage for dry matter intake and milk production in dairy cows. Anim. Feed Sci.Technol. 219: 68-76. https://doi. org/10.1016/j.anifeedsci.2016.06.007

Lestari, D.A., L. Abdullah, \& Despal. 2015. Comparative study of milk production and feed efficiency based on farmers best practices and National Research Council. Med. Pet. 38: 110-117. https://doi.org/10.5398/medpet.2015.38.2.110

Lobos, I., P. Gou, S. Hube, R. Saldaña, \& M. Alfaro. 2013. Evaluation of potential NIRS to predict pastures nutritive value. J. Soil Sci. Plant Nutr.13: 463-68. https://doi. org/10.4067/S0718-95162013005000036

Lozano, R.R. 2015. Grass Nutrition. Palibrio, Bloomington.

Mutsvangwa, T., K. L. Davies, J. J. McKinnon, \& D. A. Christensen. 2016. Effects of dietary crude protein and rumen-degradable protein concentrations on urea recycling, nitrogen balance, omasal nutrient flow, and milk production in dairy cows. J. Dairy Sc. 99: 6298-6310. https://doi. org/10.3168/jds.2016-10917

Nugroho, H.D., I.G. Permana, \& Despal. 2015. Utilization of bioslurry on maize hydroponic fodder as a corn silage supplement on nutrient digestibility and milk production of dairy cows. Med. Pet. 38: 70-76. https://doi.org/10.5398/ medpet.2015.38.1.70

Olafadehan, O. A., \& S. A. Okunade. 2018. Fodder value of three browse forage species for growing goats. J. Saudi Soc. Agric. Sci. 17: 43-50. https://doi.org/10.1016/j. jssas.2016.01.001

Ozaki, Y., S. Morita, \& Y. Du. 2007. Spectral Analysis. In: Nearinfrared Spectroscopy in Food Science and Technology. Ozaki, Y., W.F. McClure, \& A.A. Christy (Eds.). John Wiley \& Sons Inc., New Jersey. pp. 47-52. https://doi. org/10.1002/0470047704

Parrini, S., A. Acciaioli, A. Crovetti, \& R. Bozzi. 2018. Use of FT-NIRS for determination of chemical components and nutritional value of natural pasture. Italian J Anim. Sci. 17: 87-91. https://doi.org/10.1080/1828051X.2017.1345659

Phetpan, K., V. Udompetaikul, \& P. Sirisomboon. 2019. Inline near infrared spectroscopy for the prediction of moisture content in the tapioca starch drying process." Powder Technol. 345: 608-15. https://doi.org/10.1016/j. powtec.2019.01.050

Pierna, J. A.Fernández, B. Lecler, J. P. Conzen, A. Niemoeller, V. Baeten, \& P. Dardenne. 2011. Comparison of various chemometric approaches for large near infrared spectroscopic data of feed and feed products. Analytica Chimica Acta 705: 30-34. https://doi.org/10.1016/j.aca.2011.03.023

Puteri, R. E., P. D.M.H. Karti, L. Abdullah, \& Supriyanto. 2015. Productivity and nutrient quality of some sorghum mutant lines at different cutting ages. Med. Pet. 38: 132-37. https://doi.org/10.5398/medpet.2015.38.2.132

Rady, A.M., \& D.E. Guyer. 2015. Evaluation of sugar content in potatoes using NIR reflectance and wavelength selection techniques. Postharvest Biol. Technol. 103: 17-26. https:// doi.org/10.1016/j.postharvbio.2015.02.012
Riaz, M. Q., K. H. Südekum, M. Clauss, \& A. Jayanegara. 2014. Voluntary feed intake and digestibility of four domestic ruminant species as influenced by dietary constituents: A meta-analysis. Livest. Sci. 162: 76-85. https://doi. org/10.1016/j.livsci.2014.01.009

Saha, U., D. Endale, P. G.Tillman, W. C. Johnson, J.Gaskin, L. Sonon, H. Schomberg, \& Y. Yang. 2017. Analysis of various quality attributes of sunflower and soybean plants by near infrared reflectance spectroscopy: Development and validation calibration models. Am. J. Anal. Chem. 08: 46292. https://doi.org/10.4236/ajac.2017.87035

Samadi, S., Wajizah, \& A. A. Munawar. 2018. Rapid and simultaneous determination of feed nutritive values by means of near infrared spectroscopy. Trop. Anim. Sci. J. 41: 121-27. https://doi.org/10.5398/tasj.2018.41.2.121

Soldado, A., T. Fearn, A. Martínez-Fernández, \& B. De La Roza-Delgado. 2013. The transfer of NIR calibrations for undried grass silage from the laboratory to on-site instruments: Comparison of two approaches. Talanta 105: 8-14. https://doi.org/10.1016/j.talanta.2012.11.028

Sriagtula, R., P. D.M.H. Karti, L. Abdullah, Supriyanto, \& D. A. Astuti. 2017. Nutrient changes and in vitro digestibility in generative stage of M10-BMR sorghum mutant lines. Med. Pet. 40: 111-17. https://doi.org/10.5398/ medpet.2017.40.2.111

Stergiadis, S., M. Allen, X. J. Chen, D. Wills, \& T. Yan. 2015. Prediction of nutrient digestibility and energy concentrations in fresh grass using nutrient composition. J. Dairy Sc. 98: 3257-73. https://doi.org/10.3168/jds.2014-8587

Tilley, J. M.A., \& R. A. Terry. 1963. A two-stage technique for the in vitro digestion of forage crops. Grass Forage Sci.18: 104-11. https://doi.org/10.1111/j.1365-2494.1963.tb00335.x

van Soest, P. J., J. B. Robertson, \& B. A. Lewis. 1991. Methods for dietary fiber, neutral detergent fiber, and nonstarch polysaccharides in relation to animal nutrition. J. Dairy Sc.74: 3583-97. https://doi.org/10.3168/jds.S0022-0302(91)78551-2

Williams, P. C., \& D.C. Sobering. 1993. Comparison of commercial near infrared transmittance and reflectance instruments for analysis of whole grains and seeds. J. Near Infrared Spectros. 1: 25-32. https://doi.org/10.1255/jnirs.3

Williams, P. 2004. Near-Infrared Technology - Getting the Best Out of Light: A Short Course in The Practical Implementation of Near-Infrared Spectroscopy for the User. PDK Projects, Inc., British Columbia.

Wolfrum, E.J., A. J. Lorenz, \& N. deLeon. 2009. Correlating detergent fiber analysis and dietary fiber analysis data for corn stover collected by NIRS. Cellulose. 16: 577-85. https://doi.org/10.1007/s10570-009-9318-9

Yang, Z., G. Nie, L. Pan, Y. Zhang, L. Huang, X. Ma, \& X. Zhang. 2017. Development and validation of near-infrared spectroscopy for the prediction of forage quality parameters in Lolium multiflorum. PeerJ 5:e3867. https://doi.org/10.7717/ peerj.3867

Yin, Y. 2020. Model-free tests for series correlation in multivariate linear regression. J. Stat. Plan.Infer. 206: 179-95. https:// doi.org/10.1016/j.jspi.2019.09.011

Zahera, R., I.G. Permana, \& Despal. 2015. Utilization of mungbean's green house fodder and silage in the ration for lactating dairy cows. Med. Pet. 38: 123-131. https://doi. org/10.5398/medpet.2015.38.2.123 